\title{
THE FACE OF CHRISTIAN HOPE IN THE RENEWED FUNERAL RITES
}

The Second Vatican Council brought a new look at the ultimate reality of man. It has definitely contributed to the deepening of the understanding of the Christian faith and allowed to adapt its message to the needs of modern times. It was from its inspiration that, a few years after the promulgation of the Constitution Sacrosanctum concilium, the Ordo Exsequiarum was reformed, which made it possible to introduce the changes postulated by the Council's fathers into the funeral liturgy. In accordance with their provisions, the funeral rites were to express more clearly the paschal character of the Christian's death. Thus, the liturgy of the funeral became a special place for proclaiming Christian hope. It therefore seems necessary, on the basis of the texts of the renewed funeral rites, to notice its paschal character.

The proclamation of the Constitution on Sacred Liturgy during the Second Vatican Council on December 4, 1963 took place on the anniversary of the conclusion of the Council of Trent. Exactly four hundred years earlier, in the atmosphere of threatened unity of the Church and the essence of the liturgy being questioned by the reformers, a reform was carried out which was to remove the abuses and introduce uniform liturgical books valid throughout the Church. The Second Vatican Council undertook to continue these reforms under completely different conditions. According to its intentions, it did so while preserving a healthy tradition and at the same time opening the way to legitimate progress. ${ }^{1}$

* Wiktor Trojnar, MA, Roman licentiate - presbyter of the Archdiocese of Wrocław, participant of doctoral studies at the Pontifical Faculty of Theology in Wrocław, student of the Faculty of Law, Canon Law and Administration of the John Paul II Catholic University of Lublin, editor of the monograph "Via benedicta". The scholarly method of Joseph Ratzinger - Benedict XVI (Wrocław 2019); e-mail: wiktor.trojnar@gmail.com; ORCID: 0000-0003-2804-450X.

1 See: Sobór Watykański II, Konstytucja o liturgii świętej, in: Sobór Watykański II, Konstytucje. Dekrety. Deklaracje, Poznań 2002, No. 23. 
The liturgical reform program presented in the first Council document, which crowned the strivings of the liturgical movement, gave a definitive shape to what had already been maturing in the faith of the Church. The foundation of the Sacrosanctum concilium was laid out in a lecture on liturgy seen from the perspective of the history of salvation, that is, the history of God's eternal plan realized in time. ${ }^{2}$ As the Council teaches, Jesus Christ brought to mankind the fullness of Revelation through the event of His incarnation, especially the passion, death, resurrection and ascension. The reception of the paschal mystery is achieved by faith, confirmed above all in the Sacraments of Baptism and the Eucharist. ${ }^{3}$ With regard to the funeral liturgy, which seems to be the most important, the Council decided that the rite of the funeral should express more clearly the paschal character of a Christian's death. ${ }^{4}$ Furthermore, it considered it appropriate to revisit the rite of the children's funeral, with the possibility of developing an appropriate mass form. ${ }^{5}$ In the Constitution on the Sacred Liturgy, the Council states that "within the cycle of a year, [the Church] unfolds the whole mystery of Christ, from the incarnation and birth until the ascension, the day of Pentecost, and the expectation of blessed hope and of the coming of the Lord." It is in this way that the Church, making present the salvific acts and merits of her Lord, opens the faithful to the encounter with Christ and the experience of the grace of salvation. ${ }^{7}$

\section{VATICANUM SECUNDUM}

Addressing the subject of the reform of funeral rites, inspired by the Second Vatican Council, it seems indispensable to pose a question about interpretation. The key to a proper understanding of the Council's provisions and their implementation is its proper hermeneutics. This was pointed out by Benedict XVI at the very beginning of his pontificate, when, in his address to the Roman Curia, he decisively rejected and considered incorrect the so-called hermeneutics of discontinuity and break with the past, clearly advocating the hermeneutics of

See: ibidem, No. 5 .

See. S. Czerwik, Wprowadzenie do Konstytucji o liturgii świętej, in: Sobór Watykański II, Konstytucje. Dekrety. Deklaracje, Poznań 2002, p. 28-29.

4 See: Sobór Watykański II, Konstytucja o liturgii świętej, No. 81.

5 See: ibidem, No. 82.

6 Ibidem, No. 102.

7 See: ibidem. 
reform. ${ }^{8}$ According to Benedict XVI, the hermeneutics of discontinuity caused confusion and introduced a risk of division. In the Pope's opinion, such an approach opens the door to free interpretation and, above all, is based on the misunderstood nature of the Council. Explaining the meaning of the hermeneutics of the reform, Benedict XVI referred to the words of one of his predecessors. According to John XXIII, the Council was intended "to transmit pure and uncontaminated Catholic doctrine without softening or distorting it" and sought to "ensure that a reliable and unchanging doctrine, which must be faithfully respected, is deepened and presented in a way that meets the needs of our time." It is essential that the hermeneutics of reform does not break with the past, but preserves the continuity of the doctrine of the faith, while making the necessary updates. ${ }^{10}$

It is obvious that the hermeneutics of reform, which Benedict XVI juxtaposed with the hermeneutics of discontinuity and rupture, means that any renewal can only take place in continuity with Tradition. At the same time, the continuity postulated by the Pope not only does not exclude new elements, but even necessarily contains them. ${ }^{11}$ A correct interpretation of the conciliar documents is only possible from the perspective of faith. It allows us to see in the Church a common subject that ensures the unity of Tradition. The community of the Church, maintaining the identity of the historical context, develops and matures over the centuries. ${ }^{12}$ The Council will become a great power for the constant renewal of the Church on condition that it is read in the light of proper hermeneutics, that is, from the perspective of a living faith that opens the way to the interior of Tradition. ${ }^{13}$

See: Benedykt XVI, Spotkanie z kardynatami, biskupami i pracownikami Kurii Rzymskiej, "L'Osservatore Romano" 280 (2006) 2, p. 15-19.

$9 \quad$ Jan XXIII, Przemówienie w czasie uroczystego otwarcia Soboru Watykańskiego II, quote after: Kongregacja Nauki Wiary, Nota zawierająca wskazania duszpasterskie na Rok Wiary, "L'Osservatore Romano" 341 (2012) 3, p. 53.

10 See: W. Wołyniec, Czy można nauczyć się wiary na pamięć? Teologia wiary Soboru Watykańskiego II w świetle hermeneutyki reformy, in: "Otworzyć podwoje wiary". Wokót listu apostolskiego Ojca Świętego Benedykta XVI "Porta fidei”, ed. D. Ostrowski, Świdnica 2012, p. 69 .

11 See: S. Zatwardnicki, Hermeneutyka reformy czy zerwania? Benedykta XVI (Josepha Ratzingera) troska o poprawna interpretację Vaticanum Secundum, "Międzynarodowy Przegląd Teologiczny Communio" 200 (2017), 4, p. 126-127.

12 See: J. Ratzinger, Formalne zasady chrześcijaństwa. Szkice do teologii fundamentalnej, transl. W. Szymona, Poznań 2009, p. 132-133.

13 See: S. Zatwardnicki, Hermeneutyka reformy - hermeneutyka wiary, "Teologia w Polsce" 2 (2016) 10, p. $157-158$. 
One should never mummify the past, knowing well that fidelity to the spirit can only be realized through assimilation of the past over and over again. ${ }^{14}$ The pursuit of a synthesis and a natural and intuitive balance which shunts the extremes is the most characteristic feature of the methodological principles of theology. It certainly expresses a kind of respect for the truth that is being approached and learned through various complementary human efforts. ${ }^{15}$ Such an approach to theology, if we want to remain in the circle of Benedict XVI's thought, can be summarized in the concept of the hermeneutics of reform. Such a hermeneutics, careful and well thought-out, is required by statements relating to the ultimate reality of man, which have found expression in the renewed rites of the funeral.

\section{MYSTERIUM PASCHALE}

As the Second Vatican Council teaches, Christ through his passion, resurrection and ascension accomplished the work of human redemption and the perfect worship of God. ${ }^{16}$ It should be mentioned here that in contemporary theological reflection, for which the point of reference is the Holy Scripture and the writings of the Church Fathers and Christian writers, the concept of the Passover of Jesus includes not only his suffering (passio) but also his passage (transitus). This approach shows the inseparability of the two most important events, namely death and resurrection. ${ }^{17}$ In the light of the Mysterium Paschale, death is seen not so much as a punishment, but rather as an invitation to participate in God's life. Through his death, man not only participates in the laying of Christ in the tomb, but also remains in the hope of the resurrection. This truth is expressed in the words of one of the prayers accompanying the funeral rites: "Almighty God, you have overcome our death by the death of your Son, Jesus Christ, and by His glorious resurrection you have restored immortal life to us."18

Funeral rites are an expression of faith that human death is in fact a transition from mortal life to eternity. The sign of this transition is the processional transfer

14 See: J. Ratzinger, O nauczaniu II Soboru Watykańskiego. Formułowanie - przekaz - Interpretacja, ed. K. Góźdź, M. Górecka, transl. E. Grzesiuk, Lublin 2016, p. 646 (Opera omnia, vol. VII/2).

15 See: J. Szymik, Theologia benedicta, vol. I, Katowice 2016, p. 75.

16 See: Sobór Watykański II [Second Vatican Council, Constitution on Sacred Liturgy], Konstytucja o liturgii świętej, No 5.

17 See: R. Cantalamessa, Pascha naszego zbawienia, Kraków 1998, p. 175-181.

18 Obrzędy pogrzebu dostosowane do zwyczajów diecezji polskich, Katowice 2010², p. 78. 
of the body of the deceased to the grave. ${ }^{19}$ The liturgy of the funeral uses here an image of a procession of angels and saints who receive the deceased and lead him before God himself. ${ }^{20}$ The inexhaustible source of paschal hope is the Christ's resurrection, who was the first to pass from death to life. His symbol is the Paschal candle, present in the liturgy of the funeral. The flame of this candle, which is the light of the risen Christ, is to disperse the darkness of human hearts and minds. ${ }^{21}$ In the liturgy of the funeral it becomes in particular a symbol of hope for union with Christ in glory when the day of resurrection comes. ${ }^{22}$

\section{SACRAMENTA PASCHALIA}

The essence of the paschal experience is man's participation in the event of Jesus Christ. What becomes present in the mystery of worship gives an opportunity to obtain the fruit of salvation. Thanks to it, man, exceeding time and space, enters the sacramental reality. Obtaining the gifts of salvation is realized in connection with the celebration of the sacramenta paschalia, that is, the sacraments of Baptism, Confirmation and Eucharist. All the mentioned Christian mysteries must always be understood in the context of the Passover which took place in the life of Jesus Christ. Thanks to it, the newborn Christians pass through death to a new life, receive its fullness in the mystery of the Holy Spirit, and can nourish themselves with the food of the new life, that is, the Body and Blood of the Lord. This passage, expressed in sacramental signs, becomes the participation of both neophytes and all the faithful.

Christians, celebrating the commemoration of the Passover of Jesus, through the action of the Holy Spirit, can share in the death and resurrection of Christ. The celebration of the most important mysteries of the Christian faith allows the faithful to truly pass from the world of sin and death to a supernatural life which begins here on earth and will one day reach its eschatological fullness. ${ }^{23}$ The Sacraments of Christian initiation, that is, Baptism, Confirmation and the Eucharist, lead towards the fullness of life with Christ. This means that man's participation in the Paschal event takes place already at the moment of Baptism,

19 See: D. Brzeziński, Procesje w liturgii chrześcijańskiej. Geneza, teologia, duszpasterstwo, "Anamnesis" 48 (2007), p. 65-66.

20 See: Obrzęd pogrzebu..., p. 63-65.

${ }_{21}$ See: Mszat rzymski dla diecezji polskich, Poznań 2010, p. 153.

22 See: K. Konecki, Tajemnica paschalna $w$ euchologii, czytaniach biblijnych oraz w symbolach odnowionej liturgii pogrzebu, "Studia Theologica Varsaviensia" 20 (1982), p. 206-207.

23 See: W. Pałęcki, Paschalny charakter nadziei chrześcijańskiej w liturgii pogrzebowej, in: Jest nadzieja, bo jest życie wieczne, ed. B. Kulik, W. Pałęcki, Lublin 2018, p. 34. 
which is immersion in Christ's death. A description of this event can be found in the sixth chapter of the Letter to the Romans, in which the essence of baptismal liturgy is shown (v. 3). According to Paul the Apostle, death is being conformed to Jesus, which occurs in a real way. ${ }^{24}$ During the last farewell, this truth is expressed in words of prayer: "God, Creator of heaven and earth, by baptism you gave new life to a man who fell into the slavery of death, you sent our Lord Jesus Christ to conquer the power of death and rise again for the salvation of believers, you give a share in His resurrection to all who belong to Him." 25 During the funeral liturgy there is also the custom of sprinkling the coffin with holy water. This sign is accompanied by words: "Almighty God has reborn you from water and the Holy Spirit for eternal life, so let him complete the work he began at baptism.." ${ }^{26}$ Man's death should be seen as the completion of Baptism, that is, the fulfilment of Christian initiation and ultimate immersion in Christ. ${ }^{27}$ Thus, a Christian funeral should be understood as a celebration of the Paschal Mystery, in which man was already included in the sacrament of Baptism and Confirmation, and which has found its fulfilment in his death. ${ }^{28}$

The sacrament of the Eucharist is a special place of making the paschal mystery present. As the Church teaches, it is a sign of Christ's love, a nourishment on the path to eternity and the deposit of eternal life. ${ }^{29}$ The joy of participating in eternal life is rooted in the paschal Sacrifice, which is the passage from death to light and peace. The Eucharist is both an announcement of the feast of the saved in heaven and a participation in it. Hence, during the last farewell, there is a unique prayer imploring for the deceased, who "during the course of his life fed on the Body of Christ, now to be called to the feast of the children of God in heaven and, together with the Saints, to become heir to the promised eternal reward." 30 The liturgy shows eternal life as the fulfillment of the hope which the deceased placed in God. Through the Eucharist this hope is fulfilled through a special union with Christ, which is its fruit. ${ }^{31}$

See ibidem, p. 35.

25 Obrzędy pogrzebu..., p. 67.

26 Ibidem, p. 65.

27 See: B. Nadolski, Liturgika. Sakramenty, sakramentalia, błogosławieństwa, vol. 3, Poznań 1992, p. 49.

28 See: E. Mateja, Teologia nadziei w posoborowych obrzędach pogrzebowych, in: "Chlubimy się nadzieja chwaty Bożej” (Rz 5,2) Księga dedykowana ks. prof. dr. hab. Janowi Decykowi, ed. K. Filipowicz, Warszawa 2016, p. 166-168.

29 See: J. Decyk, Pascha jako szczyt roku liturgicznego, "Studia Theologica Varsaviensia" 24 (2011), p. 112-118.

30 Obrzędy pogrzebu..., p. 61.

31 See: J. Decyk, Ludzki i Boży wymiar śmierci w świetle kultu zmarlych, Warszawa 2000, p. $140-143$. 


\section{SPE SALVI FACTI SUMUS}

Faith in the mystery of Christ, His death, resurrection and ascension, is for Christians the basis of an unfailing hope that opens beyond the limits of earthly life. The basis of this hope is constituted by the risen Christ, and it has its source is His saving mission. ${ }^{32}$ The relationship between Christ's resurrection and the hope of the future resurrection is very clearly expressed in the funeral rites. The Church expresses in words of prayer the trust that the dead "together with all those who have died with Christ, will share in His resurrection." ${ }^{33}$ Likewise, the placing in the tomb is preceded by words: "Christ is the first to rise from the dead and to renew our mortal bodies in the likeness of His glorified body." ${ }^{34}$ The mourning liturgy is a testimony that the risen Christ can give people a guarantee of full and ultimate hope.

But hope can never be reduced to the conviction of certainty of universal salvation. Such a position would be based on the omission of the truth about human freedom. Man can make a negative choice by rejecting God's love and forgiveness, and thus become disconnected from communion with Christ and His Church. But this does not contradict the fact that God remains faithful to the covenant made with all mankind and desires the salvation of all the people He has created, whom He himself has destined for eternal life. ${ }^{35}$ The Church has offered her help to the deceased, who after death need purification of their sins, from the first centuries of Christianity, especially through persevering prayer. ${ }^{36}$ As the Church notes, this prayer contains a profession of faith in the existence of a state of purification. ${ }^{37}$ The conviction, present for centuries, that love can reach as far as the other world for centuries remains a comforting experience even today. ${ }^{38}$ As it was aptly expressed in the introduction to the funeral rites: "Thanks to the communion of all the members of the Church, what brings spiri-

32 See: Międzynarodowa Komisja Teologiczna, Aktualne problemy eschatologii, in: Od wiary do teologii. Dokumenty Międzynarodowej Komisji Teologicznej 1969-1996, ed. J. Królikowski, Kraków 2000, No 1.

33 Obrzędy pogrzebu..., p. 66.

34 Ibidem, p. 80.

35 See: M. Pyc, Czy mamy prawo do nadziei na powszechne zbawienie? Refleksja nad zbawczym uniwersalizmem w myśli Jana Pawła II i Benedyka XVI, "Teologia w Polsce" 3 (2009), p. $126-131$.

36 See: [Second Vatican Council, Dogmatic Constitution on the Church] Sobór Watykański II, Konstytucja dogmatyczna o Kościele, in: Sobór Watykański II, Konstytucje. Dekrety. Deklaracje, Poznań 2002, No 50.

37 See: Międzynarodowa Komisja Teologiczna, Aktualne problemy eschatologii..., No 8.

38 See: Benedict XVI, Encyclical Spe salvi, No 48. 
tual help to the deceased, to others gives comfort stemming from hope." ${ }^{39}$ In one of the prayers, the Church similarly implores for the deceased the forgiveness of sins committed because of human imperfection. ${ }^{40}$ In another one, she asks for the liberation from all sins, so that the deceased may rejoice in God without end, together with the saints. ${ }^{41}$ Finally, the Eucharistic sacrifice for the deceased on the day of his funeral is accompanied by the intention that God should cleanse $\mathrm{him} / \mathrm{her}$ of all guilt and allow him/her to join the community of saints. ${ }^{42}$

The truly Christian hope of a union with Christ is especially true at the funeral of a child. The Church expresses her conviction that a deceased child who has been baptized already has a share in eternal life, which is also emphasized by the use of white liturgical robes during the funeral. ${ }^{43}$ In prayer for the deceased child, the Church confesses the faith that God has accepted it into His kingdom. ${ }^{44}$ This faith has its foundation in the sacrament of Baptism, "through which the gates of Eden were opened before him/her." ${ }^{45}$ The prayers accompanying the last farewell of the baptized child are a testimony to the faith that its body, laid to the tomb on the day of its funeral, "will one day be resurrected and covered with the radiance of eternal life." ${ }^{46}$ Its tomb, like that of Jesus Christ, is a special sign of hope, as expressed directly in the funeral rites. ${ }^{47}$ And during the funeral of a child who has died before being baptized, the Church recommends to God especially the faithful who grieve for its loss. ${ }^{48}$ The confession of faith in the atoning death of Jesus on the cross should strengthen their confidence in God's mercy, ${ }^{49}$ and the intercession of Mary, who stood beneath the cross of her Son, is to ask for them the consolation flowing out of faith. ${ }^{50}$ Although the prayers accompanying the funeral of an unbaptized child are characterized by great caution, the liturgy of the Church makes it possible to cherish hope that children who die without baptism will be saved and enjoy seeing God. ${ }^{51}$

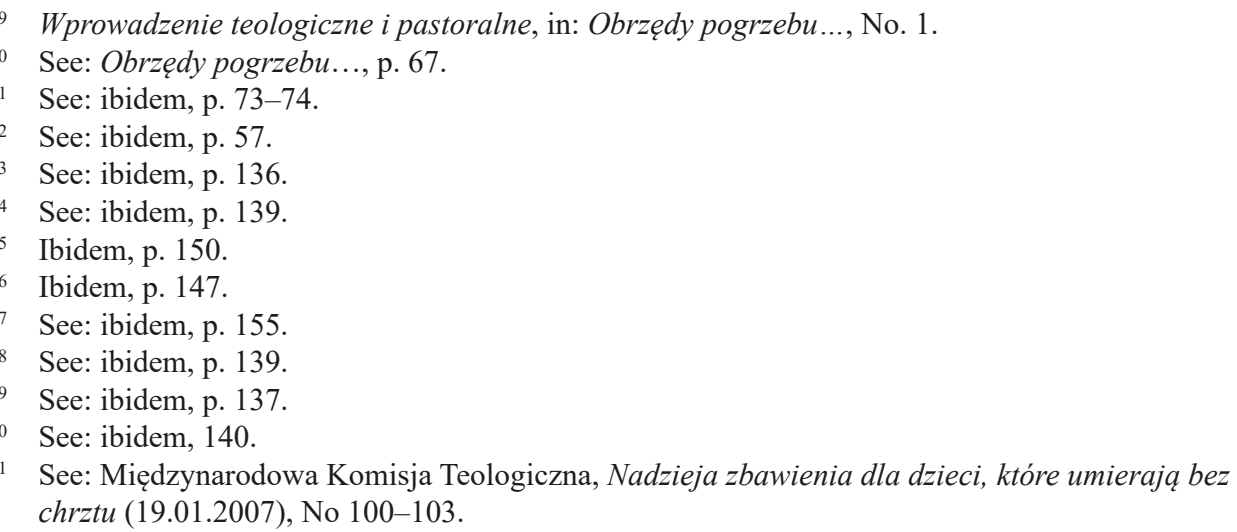


$* * *$

The Second Vatican Council, seen from the perspective of the hermeneutic of the reform, proved to be an impulse to renew the life of the Church and her mission. Beginning its work with a debate on the liturgy, it postulated, among other things, the renewal of the rite of the funeral, which from then on was to better express the paschal character of the Christian's death. The Paschal Mystery, which found its expression both in the texts of prayers and in liturgical signs and symbols, shed new light on man's ultimate destiny. Thus the liturgy of the funeral has become a special place for the preaching of Christian hope.

The renewed funeral rituals strongly emphasize Christian hope, whose source and fulfilment is Jesus Christ. He overcame the power of death through His Passover and He rose for the salvation of believers. Therefore, the salvific mission of Christ is the foundation of this hope. The essence of the paschal experience is the Christian's participation in the Mysterium Paschale. It is accomplished through the sacramenta paschalia, which give rise to Christian life of faith and develop it. They allow one to accept the gift of salvation and also raise hope for eternal life. The sacrament of the Eucharist, the centre of celebration of funeral rites, at the same time makes present and announces the feast of the saved, to which the Christian living in Christ is called. To make this truth clearer, the funeral rites also reach for the sign of sprinkling with holy water, which is a reminder of baptism. The Paschal Candle used in the funeral liturgy remains a meaningful symbol of the Risen Christ, and through the funeral procession the Church professes the faith that death in its essence is a transition to a true life with God.

Prayer for the deceased is a place to live out Christian hope and at the same time - to learn it. It is a kind of confession of faith in the possibility of their purification. The prayers accompanying a child's funeral are a special testimony of unfailing hope. The Church expresses very clearly her faith in the salvation of those children who received the sacrament of Baptism. The Paschal Mystery also becomes a source of hope for those who suffer from the death of a child who died before being baptized.

The funeral rites renewed after the Second Vatican Council open the participants of the funeral liturgy to the experience of Christian hope. Its source and fulfillment is Jesus Christ, whose resurrection opens one to the hope of new life. Both the texts of prayers for the dead and the liturgical signs and symbols accompanying them, referring to Christ the whole final reality of man, reveal the paschal dimension of this hope. Through renewed funeral rites, it is experienced by the faithful as an existing reality, giving meaning to the whole Christian life. 


\section{BIBLIOGRAPHY}

Benedict XVI, Encyclical "Spe salvi, “Acta Apostolicae Sedis” 99 (2007), p. 985-1026.

Benedict XVI, Spotkanie z kardynałami, biskupami i pracownikami Kurii Rzymskiej (2005), “L’Osservatore Romano” [Polish ed.] 280 (2006) 2, p. 15-19.

Brzeziński D., Procesje w liturgii chrześcijańskiej. Geneza, teologia, duszpasterstwo, "Anamnesis" 48 (2007), p. 62-71.

Cantalamessa R., Pascha naszego zbawienia, Kraków 1998.

Czerwik S., Wprowadzenie do Konstytucji o liturgii świętej, in: Sobór Watykański II, Konstytucje. Dekrety. Deklaracje, Poznań 2002.

Decyk J., Ludzki i Boży wymiar śmierci w świetle kultu zmarlych, Warszawa 2000.

Decyk J., Pascha jako szczyt roku liturgicznego, "Studia Theologica Varsaviensia" 24 (2011), p. 107-120.

Konecki K., Tajemnica paschalna $w$ euchologii, czytaniach biblijnych oraz w symbolach odnowionej liturgii pogrzebu, "Studia Theologica Varsaviensia" 20 (1982), p. 191-209.

Kongregacja Nauki Wiary [Congregation for the Doctrine of Faith], Nota zawierajaca wskazania duszpasterskie na Rok Wiary, "L'Osservatore Romano" 341 (2012) 3, p. 53-58.

Mateja E., Teologia nadziei w posoborowych obrzędach pogrzebowych, in: "Chlubimy się nadzieją chwaty Bożej” (Rz 5,2). Księga dedykowana ks. prof. dr. hab. Janowi Decykowi, ed. K. Filipowicz, Warszawa 2016, p. 161-171.

Międzynarodowa Komisja Teologiczna, Aktualne problemy eschatologii, in: Od wiary do teologii. Dokumenty Międzynarodowej Komisji Teologicznej 1969-1996, ed. J. Królikowski, Kraków 2000, p. 303-340.

Międzynarodowa Komisja Teologiczna, Nadzieja zbawienia dla dzieci, które umieraja bez chrztu (19.01.2007), http://www.vatican.va/roman_curia/congregations/cfaith/ cti_documents/rc_con_cfaith_doc_20070419_un-baptised-infants_it.html [access: 30.04.2020].

Nadolski B., Liturgika. Sakramenty, sakramentalia, błogosławieństwa, vol. 3, Poznań 1992.

Obrzędy pogrzebu dostosowane do zwyczajów diecezji polskich, Katowice $2010^{2}$.

Pałęcki W., Paschalny charakter nadziei chrześcijańskiej w liturgii pogrzebowej, in: Jest nadzieja, bo jest życie wieczne, ed. B. Kulik, W. Pałęcki, Lublin 2018, p. 31-47.

Pyc M., Czy mamy prawo do nadziei na powszechne zbawienie? Refleksja nad zbawczym uniwersalizmem w myśli Jana Pawła II i Benedyka XVI, "Teologia w Polsce” 3 (2009), p. $125-141$.

Ratzinger J., Formalne zasady chrześcijaństwa. Szkice do teologii fundamentalnej, transl. W. Szymona, Poznań 2009. 
Ratzinger J., O nauczaniu II Soboru Watykańskiego. Formułowanie - przekaz - interpretacja, ed. K. Góźdź, M. Górecka, transl. E. Grzesiuk, Lublin 2016 (Opera omnia, vol. VII/2).

Sobór Watykański II, Konstytucja dogmatyczna o Kościele, in: Sobór Watykański II, Konstytucje. Dekrety. Deklaracje, Poznań 2002, p. 145-263.

Sobór Watykański II [2 $2^{\text {nd }}$ Vatican Council, Constitution on Sacred Liturgy], Konstytucja o liturgii świętej, in: Sobór Watykański II, Konstytucje. Dekrety. Deklaracje, Poznań 2002, p. 48-107.

Szymik J., Theologia benedicta, vol. I, Katowice 2016.

Wołyniec W., Czy można nauczyć się wiary na pamięć? Teologia wiary Soboru Watykańskiego II w świetle hermeneutyki reformy, in: "Otworzyć podwoje wiary". Wokót listu apostolskiego Ojca Świętego Benedykta XVI "Porta fidei", ed. D. Ostrowski, Świdnica 2012.

Zatwardnicki S., Hermeneutyka reformy czy zerwania? Benedykta XVI (Josepha Ratzingera) troska o poprawna interpretację Vaticanum Secundum, "Międzynarodowy Przegląd Teologiczny Communio" 200 (2017) 4, p. 110-142.

Zatwardnicki S., Hermeneutyka reformy - hermeneutyka wiary, "Teologia w Polsce" 10 (2016) 2, p. 141-164.

Keywords: hope, eschatology, liturgy, Second Vatican Council

\section{OBLICZE CHRZEŚCIJAŃSKIEJ NADZIEI W ODNOWIONYCH OBRZĘDACH POGRZEBU}

\section{Streszczenie}

Sobór Watykański II przyniósł nowe spojrzenie na ostateczną rzeczywistość człowieka. Zdecydowanie przyczynił się on do pogłębienia rozumienia chrześcijańskiej wiary i pozwolił dostosować jej przekaz do potrzeb współczesności. To właśnie z jego inspiracji, w kilka lat po ogłoszeniu Konstytucji o liturgii świętej Sacrosanctum concilium, dokonano reformy Ordo Exsequiarum, co pozwoliło na wprowadzenie do liturgii żałobnej zmian postulowanych przez ojców Soboru. Zgodnie z ich postanowieniami obrzędy pogrzebu miały odtąd przede wszystkim jaśniej wyrażać paschalny charakter śmierci chrześcijanina. Tym samym liturgia pogrzebu stała się szczególnym miejscem przepowiadania chrześcijańskiej nadziei. Konieczne wydaje się zatem, opierając się na tekstach odnowionych obrzędów pogrzebu, dostrzeżenie jej paschalnego charakteru.

Słowa kluczowe: nadzieja, eschatologia, liturgia, Sobór Watykański II 